\title{
Power Electronics and Its Application to Solar Photovoltaic Systems in India
}

\author{
Nishij Ganpatrao Kulkarni' ${ }^{1}$, Vasudeo Bapuji Virulkar ${ }^{2}$ \\ ${ }^{1}$ Electrical Engineering Department, M.B.E. Society's College of Engineering, Ambajogai, India \\ ${ }^{2}$ Electrical Engineering Department, Government College of Engineering, Amravati, India \\ Email: nishij1@yahoo.co.in, vbvirulkar@yahoo.com
}

Received 23 April 2015; accepted 13 February 2016; published 16 February 2016

Copyright (C) 2016 by authors and Scientific Research Publishing Inc.

This work is licensed under the Creative Commons Attribution International License (CC BY). http://creativecommons.org/licenses/by/4.0/

(c) () Open Access

\begin{abstract}
Out of many renewable energy resources, solar energy is one of the conspicuous sources of energy which can supply the increasing demand of energy. As of May 2014, India has an installed PV capacity of $2.5 \mathrm{GW}$. The solar photovoltaic project includes power electronics with high quality performance devices, incorporated with smart energy management principles. Power electronics is used to improve the energy efficiency of apparatus, and help the generation of environmentally clean energy. In this article the explanation of role of power electronics and the discussion about similar and future concepts in solar photovoltaic systems related to reliability and advancement of each technology in India has been presented.
\end{abstract}

\section{Keywords}

Indian Scenerio, Power Electronics, Solar PV Systems

\section{Introduction}

Today we are facing with various problems such as global warming, climate change, pollution, formation of greenhouse gases, increase in temperature, decrease in water table, water scarcity, and depletion of ozone layer. The price of fuel is also increasing simultaneously, that is why it becomes very difficult to generate power from conventional energy sources. Due to its pollution and greenhouse gas emission, the use of traditional energy resources such as fossils fuel is not justifiable. Energy demand is increasing rapidly. So there is a mismatch between generation and requirement, leading to load shedding problems in many parts of the world. To fight against this situation, we have to focus our attention on use of renewable energy sources. The integration of power electronics with renewable energy sources such as solar and wind has a vast potential to meet the energy 
scarcity of India. In its endeavor to promote the use of renewable energy, Ministry of Renewable Energy, Government of India is providing the subsidy for installation of renewable energy projects.

Most of the industries and corporate houses are coming forward to install more and more solar photovoltaic and wind power plants to meet their electricity requirement. Solar photovoltaic systems are becoming more popular compared to wind power plants due to availability of abundant solar irradiation throughout the year and decreasing cost of PV panels. In renewable energy projects, use of power electronics devices plays an important role. This paper discusses about the various solar photovoltaic systems integrated with power electronics, in India.

\section{Indian Scenario}

In 2010 and 2011 European markets dipped, and when the National Solar Mission was announced, India was viewed with great enthusiasm by the Indian and international solar community. Often leading to disappointment, this enthusiasm has waned over the following years. Japan, Chile, the US or China markets have taken the limelight. At that time, India has built its case; it has achieved a base of $2.5 \mathrm{GW}$ of solar PV by using power electronics applications, evolved its policies and created a solar ecosystem for researchers. This can only be a first step for a country of India's size and promise [1].

Seventy percent out of installed capacity of India found in Rajasthan and the deserts of the western states of Gujarat and almost all of it is incentive-driven, utility-scale and grid connected. The past year's capacity build-up has largely been driven by the Gujarat Solar Policy and the first phase of the National Solar Mission (NSM). In 2013, there has only been 916 MW of new solar installations. This is $6.8 \%$ less than in 2012. India still ranked sixth in global capacity additions for 2013 by using power electronics applications. Nearly 1.1 GW of utility scale solar capacity added in India and another 75 MW capacity was added through rooftop projects erections, from Jan 2015 till date. Out of this 1.1 GW, 555 MW was added under NSM Phase II Batch I; the remaining are added under different state policies. The top three states in India in terms of capacity addition in year 2014 were Rajasthan (295 MW), Madhya Pradesh (220 MW) and Punjab (167 MW). The below mentioned new allocations, that will start converting in the next one or two years include Punjab phase II (250 MW), Karnataka Phase II (500 MW), Andhra Pradesh (500 MW), Telangana (500 MW), Uttar Pradesh (115 MW), and Bihar (130 MW). Hence, in total about $2 \mathrm{GW}$ of new capacity from state allocations is expected in the next one or two years [27]. To build thousands of GWs of solar power and with more than 300 days of sunshine, there is sufficient space available in India. India ranks among the highest irradiation receiving countries in the world. As on May $10^{\text {th }} 2014$, total grid connected installed capacity in India is shown in Figure 1. The solar capacity additions in India in MW from 2011 to 2013 are as shown in Figure 2. The global horizontal irradiation data of India is shown in Figure 3 [1].

The beginning of the National Solar Mission plays very important role to solar energy in India. The highlights are as follows [2].

- Installed capacity will enhance up to 20,000 MW by 2022.

- A single window investor friendly Mechanism.

- For next 30 years, planned an investment of Rs 90,000 crores.

- Government of India provided first cost of Rs 4337 crores for the first phase of the mission Target for power generation.

- For 1st Phase (ending 2013): 1300 MW (PV + CSP).

- Grid Connected (33 kV): $1000 \mathrm{MW}$ (PV + CSP).

- Rooftop PV and Small Solar: 100 MW.

- Off-Grid PV Applications: 200 MW.

The plan of US $\$ 19$ billion to produce $20 \mathrm{GW}$ of solar power by 2020, in July 2009 is to be unveiled by India, shown in Figure 4. The use of solar-powered equipment and applications would be made compulsory in all government buildings, as well as hospitals and hotels, under the plan. India was ready to generate $1000 \mathrm{MW}$ of power by 2013 on $18^{\text {th }}$ November, 2009 by launching National Solar Mission under the National action plan on climate change.

This article presents the requirement of the power electronic devices and interfaces for solar PV power generation units and collectively verifying the presently installed power electronic devices and their potential applications used in India. 


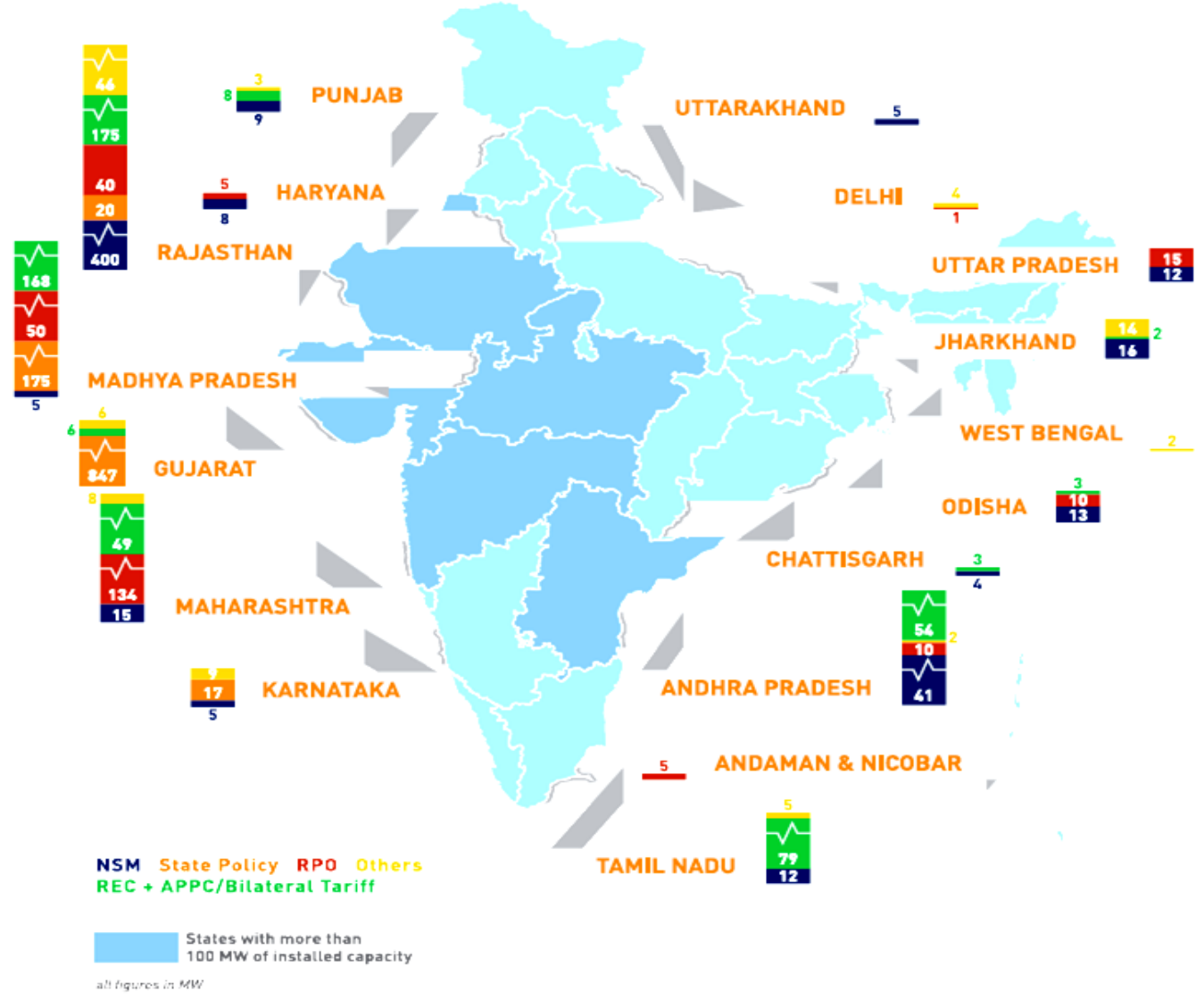

1 BRIDGE TO INDIA project database

Figure 1. International perspective over $2.5 \mathrm{GW}$ of installed PV capacity; current total grid connected Installed capacity map (as on May 10th 2014) [1].

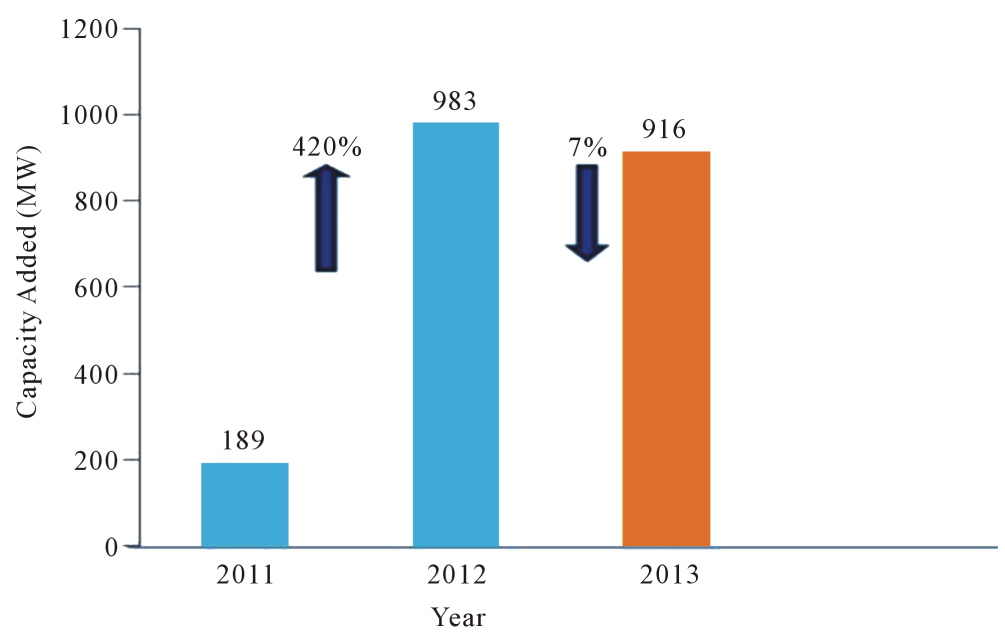

Figure 2. Solar capacity additions in India (2011 to 2013; MW) [1]. 


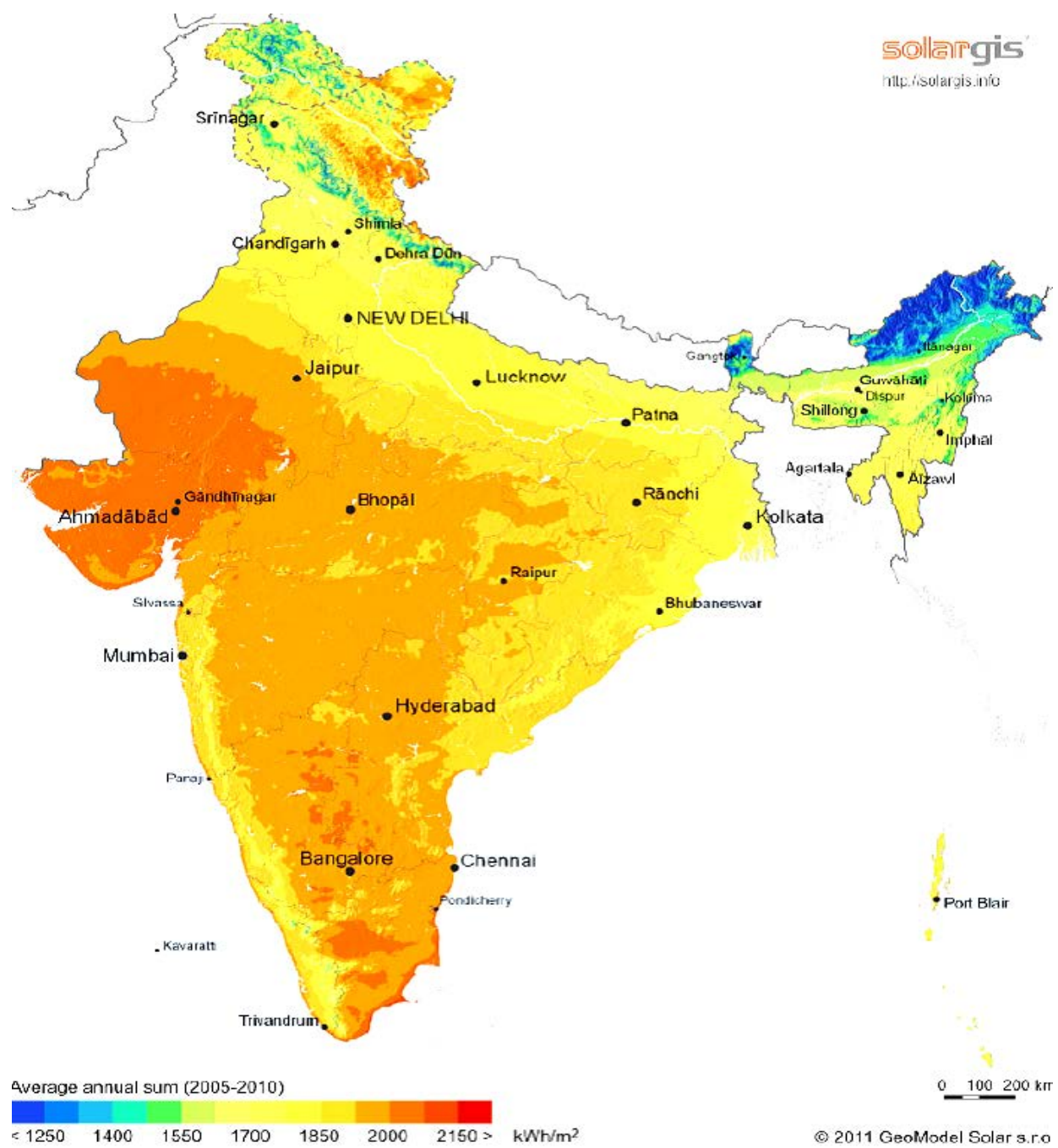

Figure 3. Global horizontal irradiation data of India [1].

Legend

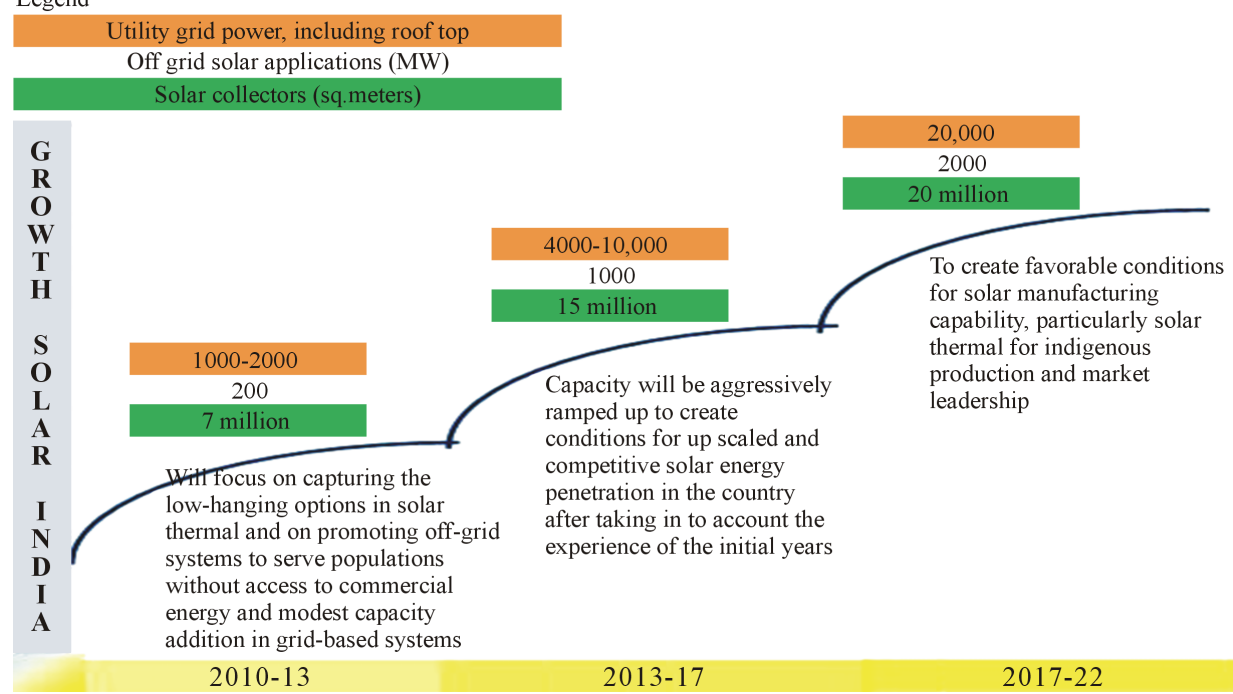

Figure 4. Plan of growth of solar power in India [1]. Source: National solar mission in India. 


\section{Photovoltaic Energy Conversion Systems}

The most widely used renewable energy is solar photovoltaic based system. PV technology is gaining significant levels and will be around in future to contribute a big share of generated electricity. Solar PV systems are based on semiconductor wafers, which produce electricity when exposed to sunlight. Thus, the electricity produced can either be stored in the batteries or sold to the electric grid. Besides these solar panels, "balance of system" components are also required which includes inverters, wiring, breakers, racking, and switches, which can account for up to half of a system's cost. According to this application, the PV systems can be segregated into four categories, namely Direct Coupled PV Systems, Stand-alone PV Systems, Grid-connected PV Systems, and Hybrid-connected Systems. In direct coupled PV systems, the PV array is directly connected to the load. Therefore, the load can operate only when the sunshine is available. Stand-alone PV systems are used in area that are not easily accessible or have no access to an electric grid. Stand-alone system is the one which is not connected to power grid and the energy produced by these systems are being stored in the batteries. In the grid-connected PV systems, electricity produced from panels are either used immediately or directly fed into the grid which is considered to be an infinite source or sink of power. A hybrid PV system is essentially a system that employs at least one more source, other than the PV, to meet the electrical power demand of the loads. Residential grid-tied solar power systems, i.e., Net Metering, will gain more popularity in the near future. Net metering provides a variety of benefits to both utilities and consumers. It can potentially reduce the utility's peak load demand. It was suggested that an improvement is required on the solar electronics' front so that the maximum utilization of solar energy can be done by PV system. Solar systems are found less efficient. The output of solar system majorly depends on shading of the module. Partial shading of PV modules will result in dramatic output reduction because the modules are connected in series. The energy from partly shaded photovoltaic system is much lower than we could assume from the mean solar irradiance [3] [4]. The panels are connected in series to enhance the power handling ability. The entire PV system made with small dc energy sources with PE power conditioning interfaces employed to improve the efficiency and reliability of the system.

The following Figure 5 [3] shows a PV system with dc-dc module used to interface the PV panels.

The PV modules consists of several solar cells which convert the energy of the sunlight directly into electricity, and are connected in series to provide desired levels of DC current and voltage. PV panel generates electricity with the help of photovoltaic effect [6]. There are various semiconductor materials used by solar cells manufactures. Most commonly used are monocrystalline Si cells, polycrystalline Si cells and amorphous Si cells. The efficiency of monocrystalline Si cells is almost $17 \%$, for polycrystalline cells reaches almost $15 \%$, while an efficiency of $10 \%$ is achieved in the case of amorphous Si PV cells. A typical current-voltage characteristic curve, for all PV modules used to make all necessary calculations, is as shown in Figure 6 [7].

\section{Power Electronics in PV Systems}

This section includes review on power generation based on photovoltaic and its implication on the related power electronic circuits. In applying power electronics, the system engineering is indispensable for improving the performance of the whole system.

The major role of Power Electronics is as follows:

1) To interconnect the individual solar panels in series and parallel according to requirement. A dc-dc converter interfacing the two solar panels that cannot be identical will help to maintain the required current and voltage, and with regulation improve the overall efficiency. Several non-isolated dc-dc converters have been employed. Buck, buck-boost, boost and Cuk topologies with suitable modifications can be employed for this purpose [5].

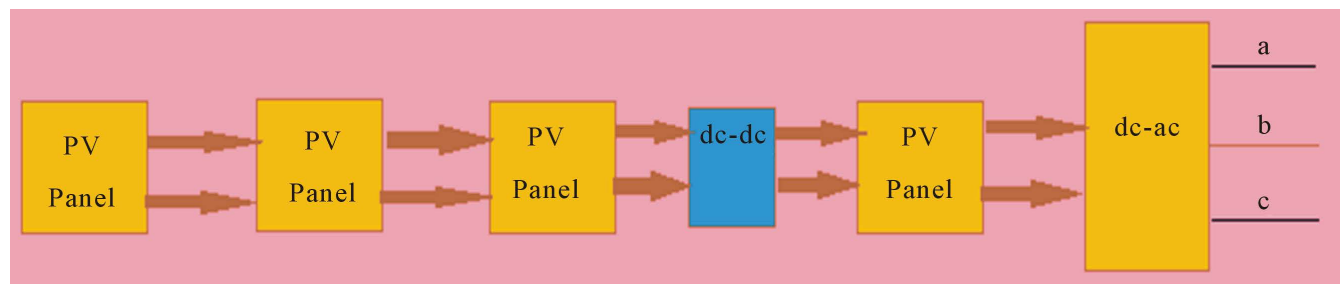

Figure 5. PV system with dc-dc module [3]. 


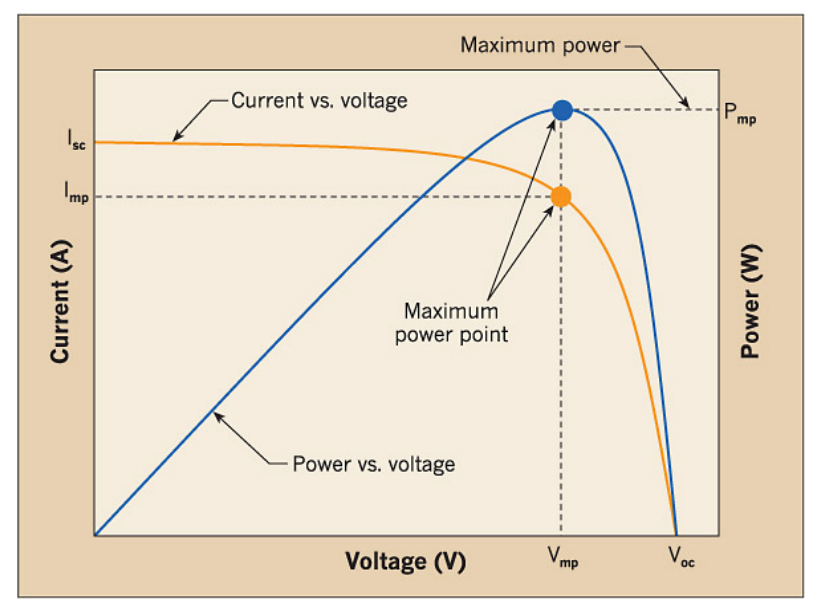

Figure 6. PV module curve [7].

2) Interfacing the dc output of the PV system to the grid or the load, this includes dc-dc-ac and dc-ac-ac conversion [23].

Where the grid is not present and the use of batteries to store energy is required, off-grid PV systems are used, in order to cover the demand during the night or whenever energy is needed. To prevent the batteries to discharge on the modules during the night, blocking diodes are used which also protect the batteries from short circuit. They also provide over-current protection of the strings in case of short circuits, if more than one string is used. Charge regulators control the charging of the batteries [6] [8]. There is the need to use dc voltage and current with stable characteristics, independent from irradiance fluctuations, in off-grid systems. Hence, a DC-DC conversion topology is used. Switch mode DC-DC converters [6] are used to match the dc output of a PV generator to a variable load.

The system types can be used as grid-direct and battery-based systems. The grid-direct systems use inverters to connect the PV array to the electric utility grid. Battery based systems acts as energy storage systems. Battery-based systems are divided into two subsystems: a stand-alone system and electric utility backup system. The classification utility-interactive system is used to analyze these systems. Utility-interactive is a general term; it can apply in grid-direct and backup systems as well, that are in parallel with the electric utility. In photovoltaic systems, PV array is connected directly to an inverter [9].

\subsection{Inverters}

In any stand-alone PV system with ac loads, power conditioning units or inverters are useful. The choice of inverter will be an important factor in setting the dc operating voltage of your system. The choice can affect the performance, reliability, and cost of PV system. The selection of the inverter input voltage is very important because it often reads the system dc voltage. The corrosive gasses of the batteries can damage the electronics components and the switching in the inverter might cause an explosion, hence the inverter should not be installed in the same enclosure with the batteries. The inverter should be installed near to the batteries and keep resistive losses in the wires to a minimum. The inverters used for grid-tie systems are available in various sizes and a range of power output values. The inverters can be classified into three general categories: micro, string, and central inverters. Micro-inverters are the smallest in size and power output ratings. These inverters are connected to a single PV module and convert DC power directly into AC. Each micro-inverter is wired to the next that parallels the AC output. String and central inverters are connected to a number of modules wired in series to form a module string. These individual strings can vary from 6 to 20 modules, depending on module and inverter voltage values. Individual strings can be placed in parallel to increase current and power input values to the inverter [3] [22].

\subsubsection{Micro-Inverters}

Micro-inverters have advantages over the more traditional string inverters. One easily known advantage is that the conversion from DC to AC is happening at the module level, which results in a number of individual mod- 
ules working independently from the modules around them. Therefore, in a shaded condition, it will not affect the performance of other modules as it would if the all modules are connected in series, as in a string inverter system. This level of control also allows installing computer-based monitoring and displaying systems which displays the power and energy values of individual modules. It is an effective tool for troubleshooting and energy production verification [9].

For mounting, the same rail system is used that supports the PV module. It includes the inverters on a rooftop, a very good environment for power electronics to reside. Micro-inverter manufacturers have constructed their products with this environment in mind, but at the time designing, they have to consider it. In addition, when an inverter fails, it requires the removal of a PV module to access, to check, to verify it. The first system of 26.52 KWp using micro invertors has been installed over an industrial unit and is in working from March 2014 successfully. It consists of 102 panels of $260 \mathrm{Wp}$, each are mounted with a $240 \mathrm{~W}$ inverters. DC cabling in addition to all the benefits of the micro inverters has been eliminated. Currently this system is generating over $27 \%$ extra power over the daily average calculated by modelling the same system for the location with string invertors. Its performance over the time frame is being monitored [10] [23] [24]. The block diagram of micro-inverter based PV system is as shown in Figure 7 [3].

\subsubsection{String Inverters}

The string inverter known as "traditional" inverter in the PV environment. There are numerous string inverter options from various inverter manufacturers. These inverters majorly used for residential installations. String inverters consist of a number of PV modules connected in series to reach the required start-up and operating voltages. String inverters require at least $200 \mathrm{VDC}$ to $250 \mathrm{VDC}$ to operate and can accept up to $500 \mathrm{VDC}$ to 600 VDC maximum. Typically, single-phase $208 \mathrm{~V}, 240 \mathrm{~V}$, or $277 \mathrm{~V}$, AC output voltages allows interconnection with most electric utility services. The string inverter installation requires the system design analysis of the PV module's output characteristics and expected temperature variations on site to calculate the number of modules connected in series to match the inverter's input requirements. Inverter manufacturer's specific tools, multiple online tools are available to assist designers in this calculation [9] [23] [24].

Proinso SL (Fustinana, Spain) recently supplied an integrated solar photovoltaic (PV) solution including Jinko modules and Zever solar string inverters to a rooftop project located close to Mumbai. This $50 \mathrm{KWp}$ rooftop PV project close to Mumbai uses Jinko $250 \mathrm{Wp}$ modules and Eversol TLC20K inverters. Modules are mounted along the slopped roof. Two $20 \mathrm{KW}$ inverters of Zever solar are wall mounted outdoors [11]. The block diagram of string-inverter based PV system is as shown in Figure 8 [3].

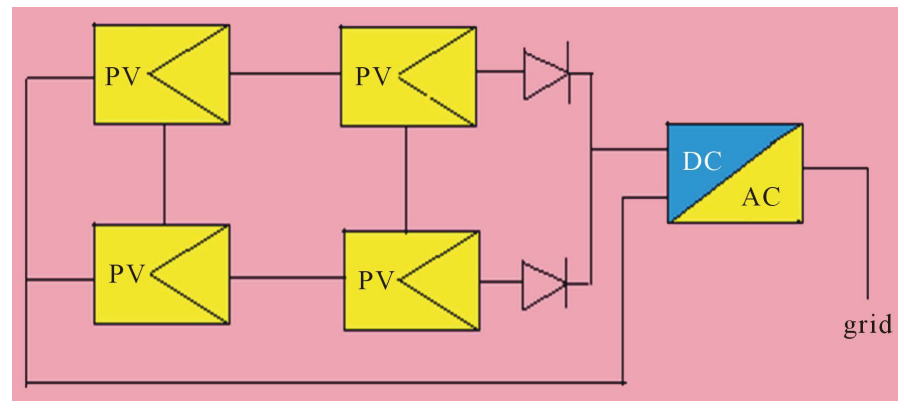

Figure 7. Block diagram of micro inverter-based PV system [3].

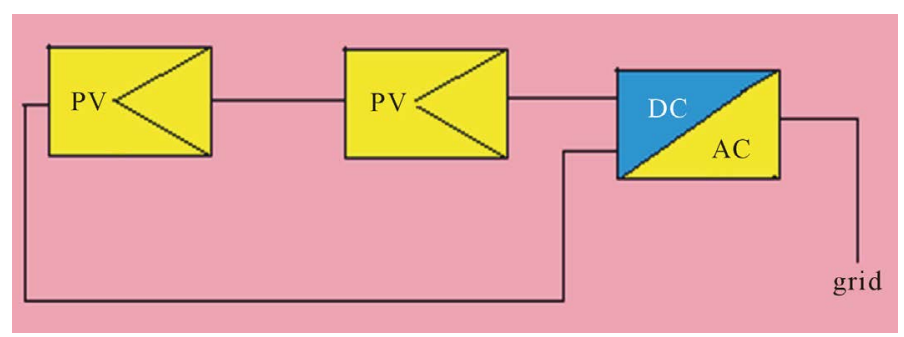

Figure 8. Block diagram of string inverter-based PV system [3]. 


\subsubsection{Central Inverters}

Central inverters are used for commercial applications. Their power output varies from $\sim 12 \mathrm{~kW}$ up to megawatt blocks. The other possibility is to connect multiple string inverters in parallel to achieve the same end result, for commercial installations. The design, erection testing of central inverters is quite similar to string inverters.

Central inverters have operating and maximum voltage ranges as similar to string inverters, with many more strings connected in parallel. Due to which the overall power and current values increases. For commercial and electric utility scale applications, some central inverters accept up to 1000 VDC. The large-scale installations are going towards the 1000 VDC systems. Most inverters come with either a 208 VAC or 480 VAC output, or with 600 VAC versions.

Central inverters available in three and four wire configurations, allowing for interconnection with both delta and star electric utility services. The central inverters are installed with display and monitoring systems so the plant operator can check any problem areas and make the operations and maintenance procedures [9]. Solar PV project in India have used central inverters. The only major known exception is the 5 MWp Solar PV project in Khimsar, Rajasthan, developed by Reliance Solar. In this plant, 432 units of SMA inverters (11 KVA each) are used [12].

At the end of 2011, almost 100 MW of central inverters have been installed in India. Biggest single plant to use central inverters will be now approximately $60 \mathrm{MW}$. The central inverter series, rated from 100 to $630 \mathrm{~kW}$, is designed for multi-megawatt PV power plants as well as large PV installations on commercial and industrial buildings [13]. The block diagram of central inverter based PV system is as shown in Figure 9 [3].

The types of photovoltaic inverters with their capacity and techniques related to it are as shown in following Table 1.

\subsection{Battery-Based Electronics}

The Charge controllers are used on the DC side of the system. Charge controllers are specified by the solar PV

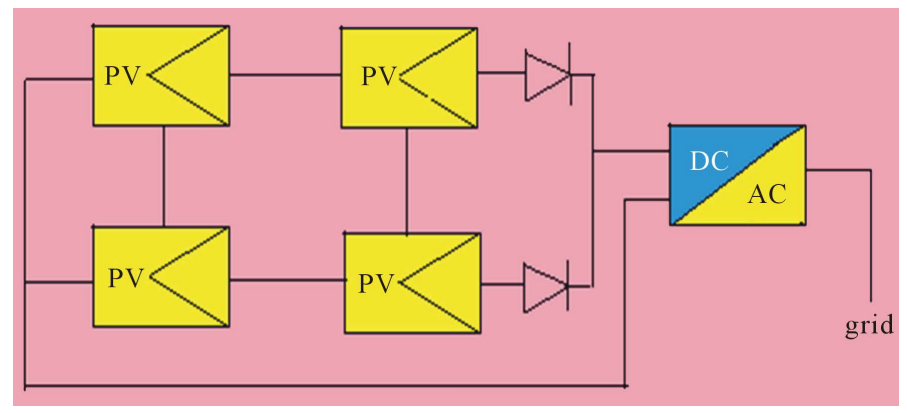

Figure 9. Block diagram of central inverter-based PV system [3].

Table 1. Types of photovoltaic inverters with their capacity and techniques. Source: Bepmax group.

\begin{tabular}{|c|c|c|}
\hline Inverter type & Capacity & Technique \\
\hline Central inverter & $250 \mathrm{~kW}$ to $01.25 \mathrm{MW}$ & $\begin{array}{l}\text { It is commonly used in MW scale photovoltaic power plants in India. } \\
\text { A single inverter controls the major portion of the plants. }\end{array}$ \\
\hline String inverter & 05 to $20 \mathrm{~kW}$ & $\begin{array}{l}\text { It is used in smaller photovoltaic installations including rooftop systems, } \\
\text { and some MW scale plants in India. A single inverter controls a single } \\
\text { or limited string of modules. They offer multiple controls at a more } \\
\text { basic level compared to central inverters, hence, reducing module } \\
\text { mismatch losses and simplifying plant maintenance. } \\
\text { They are typically mounted outdoors. }\end{array}$ \\
\hline Domestic inverter & 01 to $05 \mathrm{~kW}$ & $\begin{array}{l}\text { It is typically used for domestic rooftop applications. } \\
\text { That May be in a grid-tied or stand-alone mode. }\end{array}$ \\
\hline Micro inverter & 100 to $400 \mathrm{~W}$ & $\begin{array}{l}\text { It uses novel technology with controls the output of each module } \\
\text { individually converting it into AC. It is currently used in pilot small-scale } \\
\text { installations only, but have a promising roadmap for wide applications. }\end{array}$ \\
\hline
\end{tabular}


array voltage, current and the battery bank voltage. Two commonly used technologies for charge controllers are, pulse-width modulation (PWM) and maximum power point (MPPT). MPPT controllers can maximize the power given by the array by bucking its extra voltage to match with the battery voltage, while simultaneously boosting the current output from the array into the batteries. So the battery bank receives the full power output of the array and allows more efficient charging. A PWM controller matches the voltage from the PV array to the battery bank voltage. This can effectively leave power not used in the battery charging process. The inverters used in stand-alone and electric utility backup systems are similar in their look and functionality. The difference between them is the ability of the backup versions to push current from the DC side of the system into the AC source. This feature is disabled in stand-alone systems. These inverters are also named as power conditioning units, because they have an ability to invert the dc energy stored in the battery bank into AC and acts as charge controller unit and also protect the batteries against overcharge [9].

For a battery bank at 12 VDC, 24 VDC, or 48 VDC, Inverters are designed to invert to 120 VAC with AC power outputs varying from hundreds of watts to the $6 \mathrm{~kW}$ in market which acts as charge controller unit, acts range. Now a day, power conditioning units are also available as inverter, and also protect the batteries against overcharging. Power conditioning units with MPPT are also available in market with latest technology [3]. Improved power quality in compliance with the regulations of the utility grid can be provided by IGBTs and MOSFETs with high pulsing frequencies. Due to the high frequency used has led the use of high frequency transformers with lower weight. Due to which the total weight of the inverters reduced significantly (up to 20\%). Present string inverters vary from $22-65 \mathrm{~kg}$. The lower the weight is, the easier the installation and the lower the transportation costs. Because of the intermittent nature of renewable energy sources, sometimes because of unavailability of Sun and wind velocity no power generation takes place, at that time there is an arrangement in power conditioning units to charge the batteries through grid connection.

A power system employing photovoltaic systems mentioning the main power lines will constitute a distributed power generation (DG) system. In distributed generation system end users need not be passive consumers, but can be active suppliers to the grid. Frequency and voltage, the parameters of power delivered are monitored and controlled by the large power generator units. In case of DG systems, the power electronic interface has to change the voltage, frequency, and power to link the energy source to the grid. High power density, robust dcac and ac-ac modules with complex control and safety requirements will be focused [14].

\section{Power Electronics Applications to Solar PV Systems in India}

At Pushpagiri Institute of Medical Sciences and Research Centre, Tiruvalla, has installed $100 \mathrm{KW}$ grid interactive solar power plant. It consists of $101.43 \mathrm{kWp}$ solar photovoltaic modules; imported Leonics make grid interactive inverter and charge controller and battery. When the internal requirement is less than the generated power, the system can also feed the power back to Electricity Board (Grid) [15].

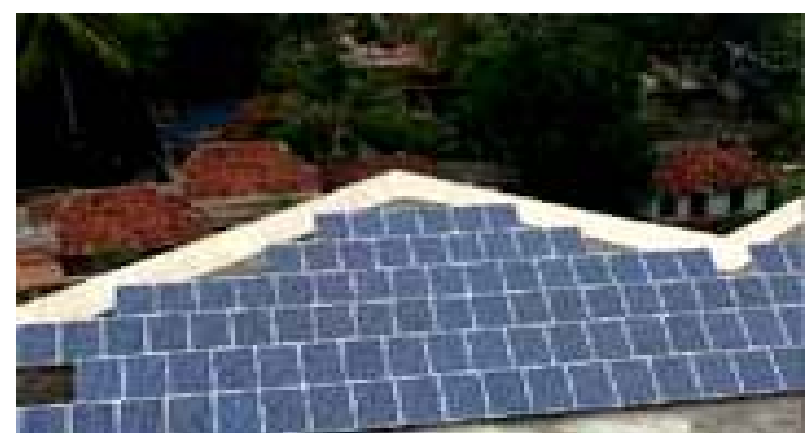

100 KW-Pushpagiri Institute of Medical Science and Research Centre, Tiruvalla Coursty: Radiant solar [15].

At Sri Parijatha Hotel, Bangalore, has installed $30 \mathrm{KW}$ Grid connected solar power plant. It consists of 30.36 KWp Solar Photovoltaic Modules, 2 numbers of Imported SMA make Grid Connected Inverter. When the internal requirement is less than the generated power, the system can also feed the power back to Electricity Board (Grid) [15]. 


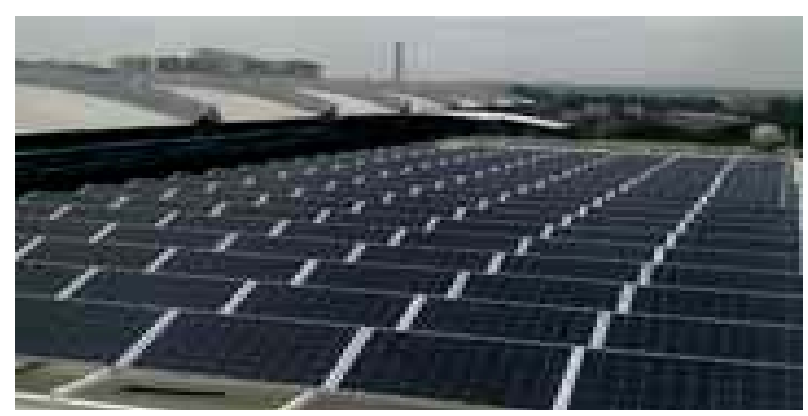

30 KW-Sri Parijatha Hotel, Bangalore Coursty: Radiant solar [15].

At Sagar Group of Institution, Hyderabad has installed $25 \mathrm{KW}$ solar power plant. It consists of $20 \mathrm{kWp}$ solar photovoltaic modules, 1number of imported Leonics make grid interactive inverter with 2 MPPT charge controllers and battery. When the internal requirement is less than the generated power, the system can also feed the power back to Electricity Board (Grid) [15].

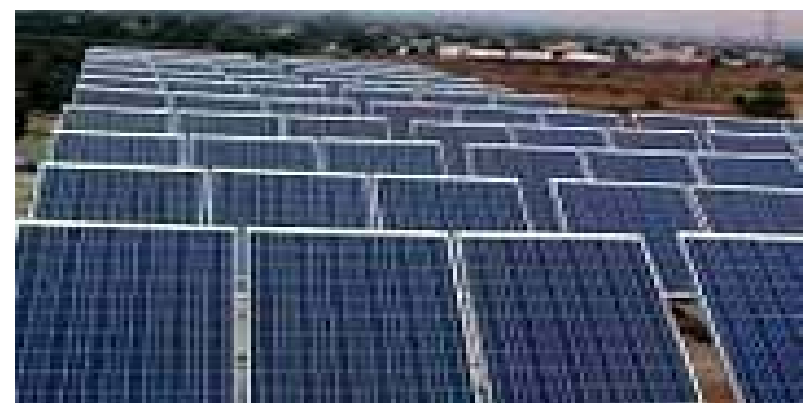

25 KW-Sagar Group of Institution, Hyderabad [15], Coursty: Radiant solar.

At Mobile Communications India Limited, New Delhi has installed 15 KW Grid Interactive solar power plant. It consists of $12 \mathrm{kWp}$ Solar Photovoltaic Modules, 1 number of Imported Leonics make Grid Interactive inverter and Battery. When the internal requirement is less than the generated power, the system can also feed the power back to Electricity Board (Grid) [15].

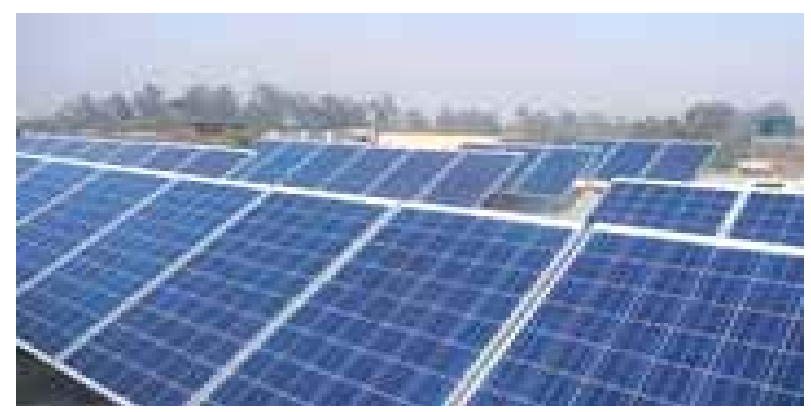

15 KW-Mobile Communications India Limited, New Delhi [15], Coursty: Radiant solar.

For Indian solar power plants, a 1 MW single module PVI 1000 outdoor switch solar inverter is used. The solar inverter series Switch PVI 1000 features a totally sealed power and controls enclosure section. On a simple concrete foundation, the inverter panels are installed outdoors. The inverters consist of a built-in self-contained cooling system. There is no need for refrigerant or external cooling water. It is self sustained. Neither external auxiliary power supply nor site plumbing is required [16]. 
Based on the detailed evaluation of the various renewable energy options, solar power has been assessed with the perspective of power electronics application on a transportation organization like the Indian railways [17].

Let us discuss about solar power in major states of India.

\subsection{Solar Power in Gujarat}

Gujarat state in India recognizes as a leader in solar power generation. It contributes 2/3rd of the $900 \mathrm{MW}$ of photovoltaic's in India. Asia’s biggest solar park commissioned by Gujarat state at Charanka village. This solar park is already generating $2 \mathrm{MW}$ solar powers, out of total planned capacity of $500 \mathrm{MW}$. The State government has launched a roof-top solar power generation scheme and made Gandhinagar, a solar city. State government have planned to generate five megawatt of solar power by putting solar panels on about 50 state government buildings and on 500 private buildings. Gujarat has planned to emulate this project in Rajkot, Surat, Bhavnagar and Vadodara in 2012-2013.

By putting solar panels on the Narmada River's canal branches, the state plans to generate solar power. The State has already commissioned a 1 MW solar plant on a branch of the Narmada Canal near Chandrasan area of Anand taluka. This also helps by stopping 90,000 liter water/year of the Narmada river from evaporating [18] [26]. The Charanka solar park of $214 \mathrm{MW}$ the largest in the world was commissioned on April 19, 2012, along with a total of $605 \mathrm{MW}$ in Gujarat, representing 2/3 of India's installed photovoltaics. The overview of various Solar PV Module technologies used in Gujarat Charanka Solar park projects, ratings of solar pv modules, Solar Inverter technology and their capacity details etc. for the Solar Projects installed at Gujarat Charanka Solar park is mentioned below in Table 2 [19].

\subsection{Solar Power in Rajasthan}

A 510.25 MW solar power generation took place at the end of the 2012-2013 in Rajasthan state of India and has passed the total photovoltaic capacity of 500 MW. Large solar parks have also been installed in Rajasthan. The 40 MW Dhirubhai Ambani Solar Park was commissioned on 31 March, 2012. A 40 MW PV power plant in Rajasthan, India, equipped with 37 SMA Sunny Central 800-CP inverters made into operation in 2013. The Nagaur PV power project is one of the largest PV power plants in India so far [20]. The Jodhpur district leads with 42 projects totaling $293 \mathrm{MW}$ in Jaisalmer and Bikaner respectively. There were 84 projects with installed capacity of 512.9. Near Sambhar Lake in Rajasthan, a 4000 MW Ultra Mega Green Solar Power Project (UMPP) is being installed. After completion, it will be the world's largest Solar Power Plant. It will build in 4 phases, with the first phase of $1000 \mathrm{MW}$ to be commissioned at the end of year 2016. The total cost of each phase of the project is estimated to be ₹70 billion (US \$1.1 billion) and approximately 7 years required it to complete [18] [26].

\subsection{Solar Power in Maharashtra}

The world's largest solar steam system is installed by the Shri Sai Baba Sansthan Trust, Shirdi. The estimated cost is of Rs. 1.33 crore, Rs. 58.4 lakh out of which was paid as a subsidy by the MNRE. The system is used to cook 50,000 meals per day for pilgrims visiting the shrine, resulting in annual savings of 100,000 kg of cooking gas and has been designed to generate steam for cooking even in the absence of electricity to run the feed water pump for circulating water in the system. Within seven months the project is installed and commissioned having a life of 25 years. A 125 MW solar photovoltaic power plant was developed by Maharashtra state generation company in Sakri taluka of Dhule district in Maharashtra, India, well equipped with central inverters, made into operation in 2013. Osmanabad region in Maharashtra has been blessed with abundance of sunlight and is ranked the third best region in India in terms of Solar insolation. A 10 MW solar power plant in Osmanabad, Maharashtra by Rely On Solar, generates approximately 18 Lac units per MW which is the highest generation in Maharashtra by any other solar power plant. This plant was commissioned in 2013 [18] [26]. In above solar plants, the power conditioning unit is equipped with (MPPT) maximum power point tracker in order to maximize the utilization of solar power. The Inverter then converts the DC available from the MPPT into an AC output comparable to the grid. The output of the inverter is filtered to reduce the harmonics to an acceptable level. The output of the inverter is always synchronized to the grid as long as the grid is available and works as a grid tied inverter and exports the power to the grid. A $10 \mathrm{MW}$ solar power plant is also installed near Latur district, used for street lighting. This is a good example of power electronics application to photovoltaic systems in India. 
Table 2. Charanka solar park projects [19]. Source solar PV modules \& inverter technology details of Gujarat, India.

\begin{tabular}{|c|c|c|c|c|c|c|c|}
\hline \multicolumn{8}{|c|}{ Gujrat-Charanka Solar Park > Overview of PV Modules \& Inverter Technology } \\
\hline Sr. No. & Name of the project & $\begin{array}{l}\text { Project size } \\
\text { (MW) }\end{array}$ & $\begin{array}{l}\text { Module } \\
\text { technology }\end{array}$ & Module make & Module rating & Inverter & $\begin{array}{l}\text { Inverter } \\
\text { capacity }\end{array}$ \\
\hline 1 & $\begin{array}{l}\text { GMR Gujarat solar } \\
\text { power pvt. Ltd., }\end{array}$ & 25 & Multicrystaline & Canadian Solar & $235 \& 240 \mathrm{Wp}$ & SMA & $500 \mathrm{KW}$ \\
\hline 2 & $\begin{array}{l}\text { Sun Clean Renewable } \\
\text { pvt. Ltd., }\end{array}$ & 6 & Thin film & Sharp solar & $128 \mathrm{Wp}$ & POWER ONE & $500 \mathrm{KW}$ \\
\hline 3 & Emami Cement Ltd., & 10 & Multicrystaline & Tata BP Solar & $230 \mathrm{Wp}$ & $\mathrm{ABB}$ & $500 \mathrm{KW}$ \\
\hline 4 & $\begin{array}{l}\text { Solarfield Energy } \\
\text { pvt. Ltd., }\end{array}$ & 20 & Thin film & Sharp solar & $128 \mathrm{Wp}$ & $\begin{array}{l}\text { Data not } \\
\text { available }\end{array}$ & $250 \mathrm{KW}$ \\
\hline 5 & $\begin{array}{l}\text { SEI solar power } \\
\text { Gujarat Pvt. Ltd., }\end{array}$ & 25 & $\begin{array}{l}\text { Data not } \\
\text { available }\end{array}$ & $\begin{array}{l}\text { Data not } \\
\text { available }\end{array}$ & $\begin{array}{l}\text { Data not } \\
\text { available }\end{array}$ & $\begin{array}{l}\text { Data not } \\
\text { available }\end{array}$ & $\begin{array}{l}\text { Data not } \\
\text { available }\end{array}$ \\
\hline 6 & $\begin{array}{l}\text { GSPC Pipavav Power } \\
\text { company Ltd., }\end{array}$ & 5 & Multicrystaline & $\begin{array}{l}\text { Data not } \\
\text { available }\end{array}$ & $\begin{array}{l}\text { Data not } \\
\text { available }\end{array}$ & $\begin{array}{l}\text { Data not } \\
\text { available }\end{array}$ & $\begin{array}{l}\text { Data not } \\
\text { available }\end{array}$ \\
\hline 7 & $\begin{array}{l}\text { AES Solar energy } \\
\text { Gujarat Pvt. Ltd., }\end{array}$ & 15 & Thin film & First Solar & $80 \mathrm{Wp}$ & Power One & $500 \mathrm{KW}$ \\
\hline 8 & Alex Astral Pvt. Ltd., & 25 & Thin film & First Solar & $\begin{array}{l}75 \mathrm{Wp}, 77.5 \mathrm{Wp} \\
\& 80 \mathrm{Wp}\end{array}$ & SMA & $800 \mathrm{KW}$ \\
\hline 9 & $\begin{array}{l}\text { NKG Infrastructure } \\
\text { Ltd., }\end{array}$ & 10 & Multicrystaline & $\begin{array}{l}\text { Data not } \\
\text { available }\end{array}$ & 230 wp & DELTA & $\begin{array}{l}\text { Data not } \\
\text { available }\end{array}$ \\
\hline 10 & $\begin{array}{l}\text { Palace solar energy } \\
\text { Pvt. Ltd., }\end{array}$ & 15 & Multicrystaline & Canadian Solar & $\begin{array}{l}\text { Data not } \\
\text { available }\end{array}$ & POWER ONE & $500 \mathrm{KW}$ \\
\hline 11 & Roha Dychem Pvt. Ltd., & 25 & Thin film & Nex Power & & SATCON & $500 \mathrm{KW}$ \\
\hline 12 & $\begin{array}{l}\text { Lanco Infratech } \\
\text { Pvt. Ltd., }\end{array}$ & 15 & Multicrystaline & C-Sun & $\begin{array}{l}230 \mathrm{Wp}, 240 \\
\text { Wp, } 245 \mathrm{Wp}\end{array}$ & BONFIGULII & $1133 \mathrm{KW}$ \\
\hline 13 & $\begin{array}{l}\text { Surana Telcom } \\
\text { Power Ltd., }\end{array}$ & 5 & Multicrystaline & Surana & $230 \mathrm{Wp}$ & AEG & $500 \mathrm{KW}$ \\
\hline 14 & GPCL & 5 & Multicrystaline & C-Sun & $250 \mathrm{Wp}$ & BONFIGULII & $\begin{array}{l}1133 \mathrm{KW} \& \\
570 \mathrm{KW}\end{array}$ \\
\hline 15 & $\begin{array}{l}\text { ZF Steering gear } \\
\text { (India) Pvt. Ltd., }\end{array}$ & 5 & Thin film & $\begin{array}{l}\text { Data not } \\
\text { available }\end{array}$ & $\begin{array}{l}\text { Data not } \\
\text { avaliable }\end{array}$ & $\begin{array}{l}\text { Data not } \\
\text { avaliable }\end{array}$ & $\begin{array}{l}\text { Data not } \\
\text { available }\end{array}$ \\
\hline 16 & $\begin{array}{l}\text { Yantra esolar India } \\
\text { Pvt. Ltd., }\end{array}$ & 5 & Thin film & Du Pont & $\begin{array}{l}\text { Data not } \\
\text { avaliable }\end{array}$ & $\begin{array}{l}\text { Data not } \\
\text { avaliable }\end{array}$ & $\begin{array}{l}\text { Data not } \\
\text { available }\end{array}$ \\
\hline
\end{tabular}

\subsection{Solar Power in Madhya Pradesh}

The largest solar power plant in India known as the Welspun Solar MP project erected on 305 hectares of land, at a cost of Rs. 1100 crores. It will supply power at Rs. 8.05. A 130 MW solar power plant, equipped with central inverters, installed at Bhagwanpur in Neemuch. The project activity uses solar PV technology for power generation there by demonstrating the viability of renewable energy generation to other project developers in the region. A 15 MW Solar Power Plant with central inverters in Kadodiya Village, Ujjain, is also installed [18] [26]. This is also a good example of power electronics application to photovoltaic systems in India. They have also planned to install another Solar Power plant in Ujjain with capacity of $30 \mathrm{MW}$.

\subsection{Solar Power in Telangana}

The second biggest solar power plant of NTPC was installed in Ramagundam with 10 MW (photo voltaic) ca- 
pacity, equipped with central inverters, on a sprawling 52.41 acres of land at a cost of Rs 88.49 crore and it was commissioned on January 29, 2014. The Power from Solar PV Modules is directed to the central inverters through the DC combiner boxes and from the inverters it is routed though the Low voltage panel to the transformer. From the transformer, the high voltage power is routed to the metering panel, load CB and eventually to grid through the high voltage panel. Within one year of commissioning of the $10 \mathrm{MW}$ solar power plant, it had generated 12.68 million units of power [18] [26]. So we have observed latest inverter technology and power electronic devices are used in the solar plant.

The state wise solar power plants installed in India are as shown in following Figure 10 [21].

The results of various schemes and solar policies in India under Renewable Energy Certificate (REC) scheme, State schemes, Renewable Purchase Obligations (RPO), through central PSU's, with contribution through various private initiatives etc. shows the developments of the solar power plants in India [25].

The Indian state wise installed capacity of solar PV projects under various policies is as shown in following Table 3 [21].

The total Grid interactive renewable in India has now reached to 30,178 MW till Jan 2014. During FY13-14, the target to install was $4325 \mathrm{MW}$ grid-connected renewables. A total of $2110.83 \mathrm{MW}$ about $48.80 \%$ has been achieved till Jan 2014. For FY13-14, the target for wind power was 2500 MW, for about 49.83\% - 1245.88 MW

Table 3. Total state wise installed solar power plants in India under various policies till January 2014 (Approx.) [21]. Source MNRE.

\begin{tabular}{|c|c|c|c|c|c|c|}
\hline \multirow{3}{*}{ State/UT } & \multirow{2}{*}{$\begin{array}{l}\text { Total MNRE } \\
\text { projects }\end{array}$} & \multicolumn{5}{|c|}{ Other programmes } \\
\hline & & State schemes & RPO & REC & Private initative & CPSUs \\
\hline & MW & MW & MW & MW & MW & MW \\
\hline Andhra Pradesh & 46.75 & & & 46.15 & & \\
\hline Chhattisgarh & 4 & & & 1.1 & & \\
\hline Gujarat & & 860.4 & & & & \\
\hline Haryana & 7.8 & & & & & \\
\hline Jharkhand & 16 & & & & & \\
\hline Karnataka & 6 & 25 & & & & \\
\hline Madhya Pradesh & 5.35 & 130 & & 59.965 & & \\
\hline Maharashtra & 47 & 150 & & 37.25 & 5 & \\
\hline Orissa & 13 & & & 2.5 & & \\
\hline Punjab & 9.325 & & & & & \\
\hline Rajasthan & 493.5 & & 40 & 133.25 & & \\
\hline Tamil Nadu & 16.05 & & & 15.7717 & & \\
\hline Uttar Pradesh & 12.375 & & & & & 5 \\
\hline Uttarakhand & 5.05 & & & & & \\
\hline West Bangal & 2.05 & 5 & & & & \\
\hline Andamar \& Nicobar & 0.1 & & & & & 5 \\
\hline Delhi & 0.885 & & & & 2.1288 & \\
\hline Others & 1.615 & & & & & \\
\hline Total & 686.85 & 1170.4 & 40 & 295.9867 & 5.1288 & 10 \\
\hline
\end{tabular}


has been installed till Jan 2014. For FY13-14 the target for solar power was 1100 MW for, about $47.59 \%$ - 524 MW has been installed till Jan 2014. As on March 31, 2014, total grid connected solar capacity in India at that time was $2632 \mathrm{MW}$.

The total grid interactive renewable in India till Jan. 2014 is shown below in Figure 11 [21].

The off-grid systems contributed with its share in total renewable energy developments in India. The total off-grid/Captive power renewable energy systems deployment in India is shown in following Figure 12 [21].

\begin{tabular}{|c|c|c|c|}
\hline \multirow{2}{*}{\multicolumn{2}{|c|}{ Capacity in MW }} & \\
\hline & & State & Capacity in MW \\
\hline & Capacity in MW & Gujarat & 860.40 \\
\hline Others & 1.615 & Rajasthan & 666.75 \\
\hline Andaman \& Nicobar & 5.1 & Andhra Pradesh & 92.9 \\
\hline Orissa & 15.5 & Arunachal Pradesh & 0.025 \\
\hline Delhi & 3.01 & Chhattisgarh & 5.1 \\
\hline Maharashtra & 237.25 & Punjab & 9.325 \\
\hline Madhya Pradesh & 195.315 & Tamil Nadu & 31.821 \\
\hline West Bengal & 7.05 & Haryana & 7.8 \\
\hline Karnataka & 31 & Uttar Pradesh & 17.4 \\
\hline Uttarakhand & 5.1 & Jharkhand & 16.0 \\
\hline Jharkhand & 16 & Uttarakhand & 5.1 \\
\hline Utter Pradesh & 17.4 & Karnataka & 31.0 \\
\hline Haryana & 7.8 & West Bengal & 7.05 \\
\hline Tamil Nadu & 31.821 & Madhya Pradesh & 195.315 \\
\hline Punjab & 9.325 & Maharashtra & 237.25 \\
\hline Chhattisgarh & 5.1 & Delhi & 3.01 \\
\hline Arunachal Pradesh & 0.025 & Orissa & 15.5 \\
\hline Andhra Pradesh & 92.9 & Andaman \& Nicobar & 5.1 \\
\hline Rajasthan & 666.75 & Others & 1.615 \\
\hline Gujarat & 860.4 & Total & $2208.4 \mathrm{MW}$ \\
\hline
\end{tabular}

Figure 10. State wise installed solar capacity till January 2014 in India; Total grid Solar power installed in India till Jan. 2014 = Approx. 2208.4 MW [21]. Source: Solar project consultancy and solutions.

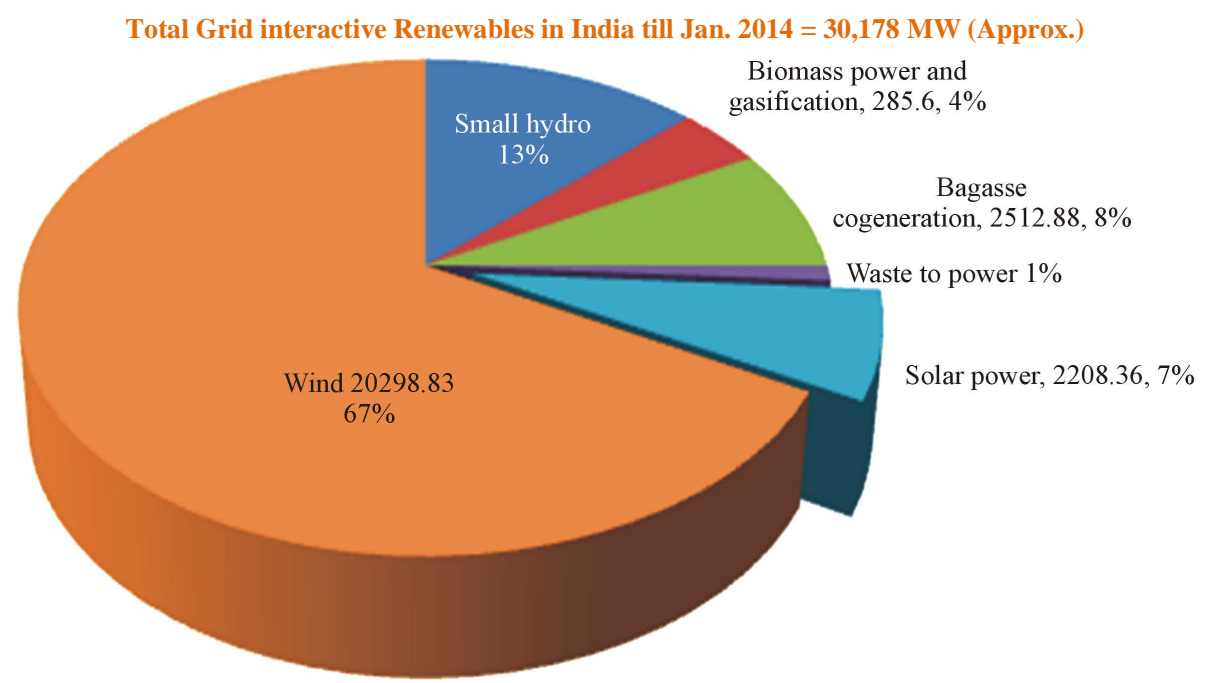

Figure 11. Total grid interactive renewables in India till Jan. 2014 [21]. Source: Solar project consultancy and solutions. 


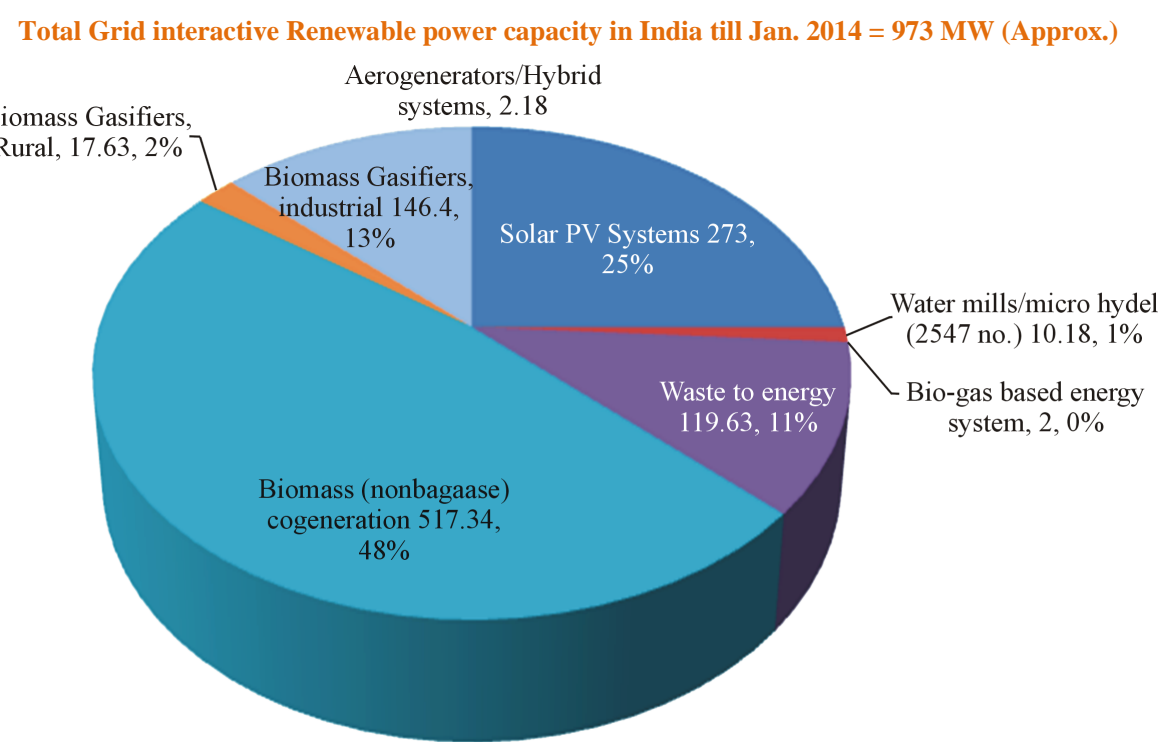

Figure 12. Total off-grid/Captive renewable power capacity in India till Jan. 2014 [21]. Source: Solar project consultancy and solutions.

\section{Conclusion}

The present article highlighted the importance of solar energy of India by using power electronics. Power electronics is used to improve the energy efficiency of devices, and help the generation of environmentally clean energy. The solar hot spots of India were also identified, with clearly identifying the power scenario. The importance of power electronics application to photovoltaic systems in India is discussed with the use of power electronics in more clear terms in respect of latest technology in inverters; maximum power point tracker and high temperature solid state fuel cells.

\section{Acknowledgements}

The authors thank All India Council for Technical Education, New Delhi (Ref. No. 20/AICTE /RIFD/RPS (POLICY-IV) 35/2012-13, March 18, 2013), India for funding this work.

\section{References}

[1] Bridge to India (2014) India Solar Handbook [Online]. http://www.bridgetoindia.com

[2] Ramar, S. (2011) Indian Solar PV Advisor. The Most Comprehensive and Detailed Guide for the Indian Solar PV Industry [Online]. http://www.eai.in/ref/reports/solar.html

[3] (2014) Indian Magazine, Akshay Urja.

[4] Blaabjerg, F., Chen, Z. and Kjaer, S.B. (2004) Power Electronics as Efficient Interface in Dispersed Power Generation Systems. IEEE Transactions on Power Electronics, 19, 1184-1194. http://dx.doi.org/10.1109/TPEL.2004.833453

[5] Walker, G.R. and Sernia, P.C. (2004) Cascaded DC-DC Converter Connection of Photovoltaic Modules. IEEE Transactions on Power Electronics, 19, 1130-1139. http://dx.doi.org/10.1109/TPEL.2004.830090

[6] Rashid, M.H. (2001) Power Electronics Handbook. Ph.D., Fellow IEE, Fellow IEEE, Academic Press.

[7] Michalis, P. (1997) Energy Production from Renewable Energy Applications. National University of Athens.

[8] Fragkiadakis, I. (2004) Photovoltaic Systems. Zito Press.

[9] Mayfield, R. (2012) Renewable Energy Associates, Electrical Construction and Maintenance. Basics of PV System Electronics. http:// http://ecmweb.com/green-building/basics-pv-system-power-electronics

[10] SQ Staff (2014) The First Darfon Micro Inverter Based PV System (Online). http://www.solarquarter.com/index.php/news/asia/india/item/270-acva-

[11] Solar Magazine (2014) Courtesy: PROINSO (Online). http://www.solarserver.com/solar-magazine/solar-news/current/2014/kw45/proinso 
[12] Nampoothiri, M. (2012) Indian Solar Industry’s Love Affair with Central Inverters (Online). http://www.re-solve.in/perspectives-and-insights/indian-solar

[13] ABB Press Release (2013) ABB Becomes a Market Leader for Solar Inverters in India (Online). http://www.abb.co.in/cawp/

[14] Kothari, D.P., Singal, K.C. and Ranjan, R. Renewable Energy Sources and Emerging Technologies. Eastern Economy Edition.

[15] Flagship Projects of Radiant Solar (Online). http://www.radiantsolar.us/flagship-projects.html

[16] Harita. Solar Inverters in India. http://www.eai.in/club/users/harita/blogs/1408

[17] Saxena, S. Study Report on Renewable Energy Strategies for the Indian Railways. Director, Research Design \& Standards Organization, Indian Railways, Technical Report. http://irsme.nic.in/files/RES-SharadSaxena

[18] Solar Power in India. http://en.wikipedia.org/wiki/Solar_power_in_India

[19] Solar PV Modules \& Inverter Technology Details of Gujarat, India_Charanka Solar Park Projects. http://urvishdave.wordpress.com/2013/03/21/charanka-solar-park-overview

[20] (2013) SMA Solar Technology AG_-Press Release. http://www.sma-india.com/uploads/media/20130306_Nagpur_Project_India.pdf

[21] Total State Wise Solar Power Installed Capacity under Various Solar Policies in India till January 2014. http://urvishdave.wordpress.com/2014/03/11

[22] Kjaer, S.B. (2005) A Review of Single-Phase Grid-Connected Inverters for Photovoltaic Modules. IEEE Transactions on Industrial Applications, 41, 1292-1306. http://dx.doi.org/10.1109/TIA.2005.853371

[23] Blaabjerg, F., Chen, Z. and Kjaer, S.B. (2004) Power Electronics as Efficient Interface in Dispersed Power Generation Systems. IEEE Transactions on Power Electronics, 19, 1184-1194. http://dx.doi.org/10.1109/TPEL.2004.833453

[24] Carrasco, J.M., Bialasiewicz, J.T., Portillo Guisado, R.C. and León, J.I. (2006) Power-Electronic Systems for the Grid Integration of Renewable Energy Sources: A Survey. IEEE Transactions on Industrial Electronics, 53, 1002-1016. http://dx.doi.org/10.1109/TIE.2006.878356

[25] Soonee, S.K., Garg, M. and Prakash, S. (2010) Renewable Energy Certificate Mechanism in India. 16th National Power Systems Conference, Hyderabad, 15-17 December 2010, 92-97.

[26] Meisen, P. (2006) Overview of Renewable Energy Potential of India. Technical Report, Global Energy Network Institute (GENI), San Diego.

[27] http://www.bridgetoindia.com/blog/as-india-adds-over-1-gw-of-solar-in-the-last-year-rajasthan-emerges-as-the-leading -investment-choice 